\title{
El marc institucional de la investigació
}

Jordi Porta

Fundació Jaume Bofill

Provença, 324, 1r. 08037 Barcelona. Spain

fbofill@fbofill.org

Intentaré exposar algunes idees sobre la recerca en ciències socials promoguda per institucions privades i, d'una manera més específica, per la Fundació Jaume Bofill que aquí represento.

$H$ e de confessar, en primer lloc, que quan em demanen que intervingui en una activitat d'aquesta universitat com a persona externa a ella, em sento una mica estrany, ja que les relacions entre la Fundació J aume Bofill i la U niversitat Autònoma de Barcelona tenen una trajectòria de molts anys i la majoria de professors dels departaments de sociologia i ciència política han tingut alguna relació amb la fundació. I crec que ha estat una bona cosa per a les dues institucions.

D ins d'aquestes ciències socials hem dedicat molts menys esforços en el camp de l'economia i el dret que a les al tres ciències socials. D 'una manera especial a la sociologia i a la ciència política. $\mathrm{H}$ em cregut que les entitats existents al nostre país que promocionaven els estudis de dret i, especial ment, econòmics, no feien tan necessària la intervenció de la fundació en aquests camps. Per tant, exclouré de les meves consideracions les recerques en els camps del dret i del'economia.

La Fundació ha promogut durant trenta anys les ciències socials amb una voluntat no estrictament acadèmica, és a dir, limitada a un augment de coneixement per ell mateix, sinó en funció d'uns objectius concrets. De fet, havíem de respondre a la pregunta de per a què serveixen les ciències socials. Tothom sap més o menys que les ciències naturals i experimentals poden millorar, per exemple, la salut de les persones i millorar el nivell de vida dels ciutadans. Però i les ciències socials, per a què serveixen?

Els poders públics fan un ús de les ciències socials relativament limitat. $\mathrm{A}$ part de l'economia i el dret, les utilitzen bàsicament per al coneixement i control de l'opinió pública. La Fundació vol anar més enllà, en el sentit que serveixin per analitzar críticament el funcionament de la societat, i no tan sols facin un diagnòstic dels problemes sinó ques'aventurin a proposar mesures per resoldre'ls. En aquest sentit, la nostra fundació té una doble manera d'actuar: com una fundació clàssica que concedeix beques i ajuts per a projectes externs que coincideixen amb les prioritats que té establertes, i com quelcom semblant al que 
ara s'anomena T hink Tank, és a dir, promou debats, encarrega anàlisis, avalua polítiques públiques, actuant com una mena de «grup de pressió ideològica». Així doncs, els principis inspiradors de la fundació són els que segueixen:

- Analitzar críticament la nostra societat, les seves bases estructurals, els seus mecanismes de funcionament i els processos d'integració i de marginació que genera.

- Interpel lar l'ordre establert amb el convenciment que no és ni l'únic pos soble ni tampoc el millor.

- Estudiar i combatre amb els mitjans que li són propis les desigualtats de tota mena, existents entre persones, entre grups i entre pobles.

- Promoure, sostenir i divulgar propostes alternatives tant de pensament com d'organització i d'acció social.

- Contribuir a l'afirmació nacional de Catalunya en el marc del respecte i de la promoció dels drets dels pobles.

I més en concret, per al període del 1997 al 2000, la fundació té previstes quatre àrees prioritàries d'actuació:

- Perfeccionament de la democràcia: participació ciutadana, revisió del fun cionament democràtic, comportament electoral...

- Acolliment dela immigració: aplicació de la Llè d'estrangeria, segones gene racions i escola, formació de mediadors, interculturalitat...

- M illora de l'educació: aplicació de la reforma educativa, promoció de noves eines didàctiques, educació ètica...

- D esenvolupament cultural : anàlisi de producció i consum cultural, polítiques culturals europees, noves tecnologies i cultura...

El tema de la utilitat de les ciències socials, a parer meu, es pot analitzar a partir de quatre nivells de possible mesura de l'ús de la recerca:

- Una recerca és útil per la mateixa persona que la fa, en la mesura que augmenta la seva competència professional i millora el seu currículum.

- Q uan, a més, hi ha una comunicació amb els col·legues de la seva mateixa especialitat, pot provocar un debat fructífer a l'interior de la seva disciplina.

- Si aconsegueix fer arribar els resultats de la recerca als agents socials i polítics, pot intentar modificar les polítiques respectives en funció dels resultats de la seva recerca.

- Si, finalment, pot arribar als creadors d'opinió dels mitjans de comunicació, la seva recerca pot contribuir a la creació d'opinió pública respecte al tema.

Crec que és convenient observar, en cada cas, el nivell al qual ha arribat la recerca per tal de mesurar-ne la utilitat social. No cal, evidentment, que 
es compleixin els quatre nivells, però sí que és convenient tenir-los presents.

Aquesta seria una manera d'equiparar la utilitat de l'activitat en les ciències socials amb al tres activitats. Si les empreses mercantils poden mesurar l'eficàcia de la seva activitat amb criteris de compte de resultats i de beneficis econòmics i la recerca en ciències experimentals amb criteris d'aplicació per millorar les condicions materials d'existència, les ciències socials haurien de guanyar la confiança en la seva utilitat a partir de la capacitat quetenen de fer més transparent el funcionament de la nostra societat i d'indicar possibles mesures per millorar-la. 